\title{
Alabalık İşletmeleri ve Delphi Anket Yöntemi
}

\section{Hülya SAYĞI*, Mehmet Ali CANYURT, Yusuf GÜNER, Fatih GÜLEÇ, Gizem IŞIK}

\author{
Ege Üniversitesi Su Ürünleri Fakültesi Yetiştiricilik Bölümü, İzmir
}

Geliş : $\quad 26.11 .2015$

Kabul : $\quad 09.03 .2016$

*Sorumlu Yazar: hulya.saygi@ege.edu.tr

Bas1lı ISSN: 1300 - 4891E. Dergi ISSN: 1308 - 7517

\section{Özet}

Küreselleşmenin hızlandığı günümüzde su ürünleri sektörünün özellikle su ürünleri işletmelerinden Alabalık işletmelerinin önemi gün geçtikçe artmaktadır. Bu araştırmada Tarım, Gıda ve Hayvancılık Bakanlığı kayıtlarından alınan Türkiye'deki alabalık işletme adresleri kullanılmıştır. Bu alabalık tesislerine Delphi anket yöntemi uygulanmıştır. Anket sonuçlarında elde edilen uzman görüşlerine göre Türkiye' de alabalık yetiştiriciliğinin sorunlarını çözümlenmesi ve gelişmesine yönelik yapılması gerekenler şunlardır; İşletme açmak, üretimde devamlılı̆̆ sağlamak ve üretilen malı pazara sürmek için gerekli olan bürokratik formaliteler azaltılmalıdır. Üretimin kaliteli ve yüksek verimde yapılabilmesi için hastalıktan ari yavru ve yumurta üretimi teșvik edilmelidir. Yem fiyatları yüksektir. Bu nedenle yem kalitesi düșürülmeden fiyatlarda indirime gidilmelidir. Alınan vergilerin azaltılması bu sorunun çözümünde iyi bir adım olabilir. İşletmelerin kredi gereksinimlerinin giderilmesine yönelik kredi sağlayan kuruluşların işletmelerin mevcut durumlarını dikkate alarak alternatif şartlar geliştirmesi yarar sağlayacaktır. Gerek işletmelerin kuruluş aşamasında, gerekse üretim aşamasında ilgili kurumlarca işletmelere yeterli düzeyde teşvik sağlanmalıdır. İşletmelerde genel olarak karşılaşılan sorunların ç̧̈zümünde kooperatifleşmeye gidilmesi şarttır. Sonuç olarak, Türkiye'nin çeşitli bölgelerinde alabalık yetiştiriciliği sektörü içinde aktif olarak çalışan uzmanların ortaklaşa belirledikleri sorunların uygun bir biçimde çözümlenmesiyle, sektörün ülkemizde gerek ekonomik gerek bilimsel olarak ilerleme kaydedeceği açıkça görülmektedir.

Anahtar kelimeler: Delphi Tekniği, Yetiştiricilik, Alabalık İşletmeleri, Türkiye.

\section{Trout Enterprises and the Delphi Survey Methodology}

\begin{abstract}
The importance of trout enterprises which are the ones out of particularly fishery enterprises of fishery sector is gradually increasing in these days during which the globalization has gained speed. In this study the addresses obtained from the ministry of food, agriculture and livestock records were used. The Delphi survey methodology was applied to these trout enterprises. The followings have to be done to solve the problems of trout farming and to develop the trout farming according to expert opinions obtained from the survey results: establishing a trout enterprise, providing continuity in production and reducing the bureaucratic formalities required for putting the produced good on the market. Production of baby trout and egg free from any disease has to be promoted to provide a production of good quality and high efficiency. Fish-feed prices are high. Thus, the prices should be reduced without reducing the feed quality. Reducing the taxes may be a good option to solve this problem. It will be useful that the credit institutions provide alternative conditions to meet the credit requirements of the enterprises by taking into consideration the current situations of the enterprises. The enterprises should be promoted by the relative institutions both during establishment phase of the enterprises and the production phase. For the solution of the problems generally encountered in the enterprises, it is an obligation to become a cooperative. As a result, it is obvious that this sector will make progress both economically and scientifically by solving the problems determined by the experts working actively in trout farming sector in different regions of Turkey in a suitable way.
\end{abstract}

Keywords: Delphi Technique, Aquaculture, Trout Enterprises, Turkey. 


\section{INTRODUCTION}

Aquaculture production is carried out in two different ways: sea and inland water fishing, aquaculture in seas and territorial waters (culture fishing).

For a sustainable fishing, the amount of the fishable fishes has reached to the top level (Table 1). World aquaculture production (except from aquatic plants) has become 154 tons, 90.4 of which was acquired with aquaculture and 63.6 of which was acquired with aquaculture. The annual value of the production made by fishing and aquaculture is 217.5 billion dollars.

Table 1. World's Fishing and Aquaculture Production (2000-2011) (FAO 2012)

\begin{tabular}{|c|c|c|c|c|c|c|c|c|c|}
\hline \multirow[b]{3}{*}{ Year } & \multirow[b]{3}{*}{$\begin{array}{l}\text { General } \\
\text { Total }\end{array}$} & \multirow{2}{*}{\multicolumn{3}{|c|}{$\begin{array}{l}\text { Fishing } \\
\text { (Million tons) }\end{array}$}} & \multirow[b]{3}{*}{$\%$} & \multirow{2}{*}{\multicolumn{3}{|c|}{$\begin{array}{l}\text { Aquaculture } \\
\text { (Million tons) }\end{array}$}} & \multirow[b]{3}{*}{$\%$} \\
\hline & & & & & & & & & \\
\hline & & Seawater & $\begin{array}{l}\text { Inland } \\
\text { water }\end{array}$ & $\begin{array}{l}\text { Sea+ } \\
\text { Inland } \\
\text { water }\end{array}$ & & Seawater & $\begin{array}{l}\text { Inland } \\
\text { water }\end{array}$ & $\begin{array}{l}\text { Sea+ } \\
\text { Inland } \\
\text { water }\end{array}$ & \\
\hline 2000 & 130.7 & 86.0 & 9.2 & 95.3 & 73.0 & 14.2 & 21.3 & 35.5 & 27.0 \\
\hline 2001 & 131.0 & 84.2 & 8.7 & 93.0 & 71.0 & 15.4 & 22.6 & 38.0 & 29.0 \\
\hline 2002 & 133.6 & 84.5 & 8.7 & 93.2 & 70.0 & 16.4 & 24.0 & 40.4 & 30.0 \\
\hline 2003 & 133.2 & 81.5 & 9.0 & 90.5 & 68.0 & 17.2 & 25.5 & 42.7 & 32.0 \\
\hline 2004 & 140.5 & 85.7 & 8.9 & 94.6 & 67.0 & 18.1 & 27.8 & 45.9 & 33.0 \\
\hline 2005 & 142.7 & 84.5 & 9.7 & 94.2 & 66.0 & 18.9 & 29.6 & 48.5 & 34.0 \\
\hline 2006 & 137.3 & 80.2 & 9.8 & 90.0 & 66.0 & 16.0 & 31.3 & 47.3 & 34.0 \\
\hline 2007 & 140.2 & 80.4 & 10.0 & 90.3 & 64.0 & 16.6 & 33.4 & 49.9 & 36.0 \\
\hline 2008 & 142.6 & 79.5 & 10.2 & 89.7 & 63.0 & 16.9 & 36.0 & 52.9 & 37.0 \\
\hline 2009 & 145.3 & 79.2 & 10.4 & 89.6 & 62.0 & 17.6 & 38.1 & 55.7 & 38.0 \\
\hline 2010 & 148.5 & 77.4 & 11.2 & 88.6 & 60.0 & 18.1 & 41.7 & 59.9 & 40.0 \\
\hline 2011 & 154.0 & 78.9 & 11.5 & 90.4 & 59 & 19.3 & 44.3 & 63.6 & 41.0 \\
\hline
\end{tabular}

The world's aquaculture consumption per capita is $16.3 \mathrm{~kg} / \mathrm{year}$. This rate is 23.8 $\mathrm{kg} /$ year in developed countries while it is $14.3 \mathrm{~kg} /$ year in developing countries. The world's aquaculture consumption is fresh by $48 \%$, frozen by $26 \%$ and conserved by $15 \%$.

In $2011,67.9 \%$ of the production was made from the sea and $5.3 \%$ was made from the inland waters both by means of fishing and $26.8 \%$ of the production was made by means of aquaculture in Turkey. The distribution of 703.545 tons of production is as follows (Table 2). 
Table 2. World's Fishing and Aquaculture Production in Turkey (2000-2011)

(TUIK, 2011)

\begin{tabular}{llllllllll}
\hline \hline & & \multicolumn{7}{c}{ Fishing } & \multicolumn{5}{c}{ Aquaculture } \\
\cline { 3 - 8 } Years & & $\begin{array}{l}\text { General } \\
\text { Total }\end{array}$ & Seawater & $\begin{array}{l}\text { Inland } \\
\text { water }\end{array}$ & $\begin{array}{l}\text { Sea+ } \\
\text { Inland } \\
\text { water }\end{array}$ & \% & Seawate & $\begin{array}{l}\text { Inland } \\
\text { water }\end{array}$ & Sea+Inlan \\
water & \% \\
\hline 2000 & 582.4 & 460.5 & 42.8 & 503.3 & 86.4 & 35.7 & 43.4 & 79.0 & 13.5 \\
2001 & 527.7 & 484.4 & 43.3 & 527.7 & 88.6 & 29.7 & 37.5 & 67.2 & 11.3 \\
2002 & 627.8 & 522.7 & 43.9 & 566.6 & 90.3 & 26.9 & 34.3 & 61.2 & 9.7 \\
2003 & 587.7 & 463.1 & 44.7 & 507.8 & 86.4 & 39.7 & 40.2 & 79.9 & 13.6 \\
2004 & 644.5 & 504.9 & 45.6 & 550.5 & 85.4 & 49.9 & 44.1 & 94.0 & 14.6 \\
2005 & 544.8 & 380.4 & 46.1 & 426.5 & 78.3 & 69.7 & 48.6 & 118.3 & 21.7 \\
2006 & 662.1 & 489 & 44.1 & 533.1 & 80.5 & 72.3 & 56.7 & 129.0 & 19.5 \\
2007 & 772.2 & 589.1 & 43.3 & 632.4 & 81.9 & 80.8 & 59.0 & 139.8 & 18.1 \\
2008 & 646.3 & 453.1 & 41 & 494.1 & 76.5 & 85.6 & 66.6 & 152.2 & 23.5 \\
2009 & 623.1 & 425.1 & 39.2 & 464.3 & 74.5 & 82.5 & 76.3 & 158.8 & 25.5 \\
2010 & 653.2 & 445.7 & 40.3 & 486.0 & 74.4 & 88.6 & 78.6 & 167.2 & 25.6 \\
2011 & 703.6 & 477.7 & 37.1 & 514.8 & 73.2 & 88.3 & 100.5 & 188.8 & 26.8 \\
\hline \hline
\end{tabular}

Turkey has inland waters, supplies of fresh water and seashores all suitable for culture fishing. As the aquaculture aquaculture was developed, the amount of produced haul has shown an increase of $240 \%$ since 2002.

According to the data of 2012 on the culture fishing in Turkey, there are 2163 active enterprises in total 1791 of which produce fresh water fish and 372 of which produce sea fish. In Turkey, the most significant species cultivated is trout by $60 \%$ in fresh waters, sea bass by $26 \%$ and gilt-head bream by $18 \%$ in seas. Among the Turkey's inland water fish production, the trout (Oncorhynhcus mykiss) haul comes in first by an amount of nearly 100 thousand tons (TUIK, 2011).

Enterprises producing trout in our country and in the World have many problems. There is a need of a scientific research and determination of solution proposals for the resolution of these problems. Delphi technique which is a data collection approach has been used since it has never been used before in the researched related to aquaculture.

Determining the problems of the trout enterprises in Turkey, this study has set solution proposals by estimating the effect of these problems to the socio-economic and environmental tendencies.

\section{MATERIAL and METHODS}

A method called Delphi has been widely used for almost fifty years on information and communication field, in service and consumption sectors, on administration and production, in chemistry sector, in studies related to health and in various fields such as 
agriculture and nourishment, environment and its resources, energy and its resources, construction and residential sector (Woudenber, 1991).

Delphi technique was developed by two researchers named Olaf Helmer and Norman Dalkey working in RAND (Research And Development) in USA in 1950s in order to make predictions about unknown or unobserved cases based on known or observed situations (Dalkey and Helmer, 1962). In the resolution of a problematic case, researches generally face situations such that the arbiters approach the case from different points of view and that the opinions contravene each other sometimes. These difference of opinions may be on questions such as what targets would be suitable to be present in the training program, which qualities the product should have, whether an activity planned to be carried out would be worth doing or not, what priorities can be set, what competence someone who is to carry out a specific duty should have etc.

Delphi technique is used as a means of providing a consensus in cases where there are differences of opinion regarding such situations. Being defined as a means of providing consensus, Delphi is a technique which systematically acquires expert opinions on a problematic situation. They describe Delphi technique as forming a structure where a group of individuals can communicate effectively in order to overcome complex problems (Saekman, 1975 and Quinn, 1986).

In general terms, Delphi technique has three qualities such as 1) confidentiality in participation, 2) Statistical analysis of group's reaction, 3) Controlled feedback.

One can talk about the superiorities and the limits of the Delphi technique. Delphi technique minimizes the risk of problems which may arise from the case where individuals come face to face. In this way individuals may state their ideas freely without being exposed to the pressure coming from others. As a result of the feedbacks acquired by the sequence questionnaires, participants are informed about the different ideas and a structure where a group of individuals may communicate effectively in order to overcome complex problems is built (Linstone and Turoff, 1975). It provides significant advantages in the case where data are to be acquired from so many participants, when there is no possibility for the participants to gather frequently because of the reasons such as time, venue, distance, cost, where power struggle, political struggles and conflicts cannot be overcome on face to face encounters (Turoff and Hiltz, 2001).It provides an opportunity for them to review their ideas and for the individuals to contribute the related parts of the problems from different points of view with the help of different information, skills and experiences. In the researches where Delphi technique is used, experts are selected. In such a selection the selected ones may see themselves to be privileged. This situation provides a motivating development. They realize that Delphi technique is an application more complex than other questionnaires and pay attention to this. In the case where the data are to be acquired from so many participants, where there is no possibility for the participants to gather because of reasons such as time, venue, distance, cost, some limitations regarding Delphi technique can be mentioned as well. In this technique which is based on the confidentiality of the participants, the phrases used in the questionnaires may be descriptive for individuals and groups. Delphi method functions via sequence questionnaires. For this reason, it is vital to keep the participants confidential in this process. If the participants first join the research and then resign from it, this may cause a problem. In order to overcome this problem, briefing participant on the overall research (number of questionnaires, term of each application, the time when they will be 
concluded, the conclusion of each application) would be useful. It would be also effective to make a payment to the participants. . Despite some limitations, Delphi technique may be used as a means of providing consensus. Particularly, the principle of confidentiality in participation which is an aspect of this technique may provide different and creative ideas to appear. In the Delphi process, using sequence questionnaires and giving feedback to the participants related to the analysis provide opportunity for the participants to review their and others' ideas, and to take a step towards a consensus. Evaluation may be helpful and directive for many administrative/planning and inventor institutions. The other important contribution of the study is how expert groups, which are formed by gathering people from different environments (academic area, private sector, public institutions etc.), provide consensus in evaluating the effects of the projects on tendencies and how they differentiate from one another. Delphi technique can be used particularly in the cases where a decision is to be made in political or sentimental environments or where the decisions are susceptible to be affected by powerful groups (Linstone\&Turoff, 1975).

While applying the three-stage Delphi Method in order to determine the problems faced in trout enterprises in Turkey, the following steps are taken : the names and addresses of the inland water facilities belonging to the trout enterprises which produce 100 tons per year in Turkey are obtained from the Ministry of Food, Agriculture and Livestock on 31/12/2010. Application of Delphi technique has a series of stages which are aimed at revealing, examining the approaches and points of view belonging to of the experts in determined Trout enterprises (Turoffand Hiltz, 2001; Sahin, 2001; Duvarci et al., 2008) or of the target group's representatives (Rothwell and Kzansas, 1997) and at providing a consensus. The tendencies in the problems of the Trout production enterprises which have arisen by now have been determined.

An expert group which can evaluate these tendencies is formed. In this study the group of experts is selected out of 406 enterprises making a production of 100 tons or more per year among 1762 enterprises active in trout aquaculture in Turkey. Contacts have been made with around 30 of these enterprises. Only 10 enterprises among those which were contacted volunteered to participate in the study. For the effect evaluation, data have been collected from the expert group. Data have been analyzed and its results were interpreted within the frame of recommended method.

The stages of the Delphi method:

1. Determination of the problems,

2. Selection of the Panel Members (Participants) : Panel members should have the quality to represent the expert opinions. According to their experiences and qualities panel members should provide a deep view and have important ideas about the subject. Using Delphi technique it is possible to work with an expert group having a big or small number. It should be a group composed of at least 7 experts. The group span can be 100 or more. The ideal group size should be composed of 10-20 experts. For the example given in the first article, the expert groups are composed of the academicians in the related departments of the universities and enterprises in the employment areas.

3. Sending the open-ended questions related to the problems of the research (First Delphi Questionnaire) to the participants,

4. Answering the first Delphi questionnaire, asking each participants to list their ideas related to the questions posed and to send them to the researchers anonymously, 
5. Drawing up the second Delphi questionnaire and sending it;listing the ideas stated by the participants in the First Delphi Application and if required gathering them under sub-titles.

6. Answering the second Delphi questionnaire; the participants shall be asked to determine the importance level of both article or participation level of each article on likert scale,

7. Analysis of the second Delphi questionnaire is calculated with the first quarter, second quarter, square and span values of each article (Rowe, Wright and Bolger, 1991; Guven et al. 2006).

8. Drawing up the third Delphi questionnaire and sending it; third Delphi questionnaire is the same as the second.

9. Answering the third Delphi questionnaire; the third Delphi questionnaire is submitted along with the statistical results to the participants again.

10. At the last stage, the analysis of the third Delphi questionnaire and the finalization of the applications; the statistics made in the application of the second Delphi are used for the analysis of the third Delphi questionnaire.

\section{Findings}

The research problem is defined with one single sentence in a way that all participants understand the same sense:

"What are the problems faced by the trout enterprises active in Turkey?"

"Please, list as many problems as possible regarding the subject." "These questions that you fixed shall be gathered with the statements of other participants and Second Phrase Delphi Questionnaire shall be drawn up" have been sent. Competence Articles Acquired from the First-Stage Delphi Questionnaire:

1. Pre-study (Agriculture Institution or other institutions of the city) is enough in the project stage.

2. There are problems faced in the stage of renting.

3. A production planning is made according to regions and the conditions of the environment.

4. Official figures (eggs, fry and portion) represent production figures.

5. The Ministry should have a sufficient number of staff for fighting with the diseases.

6. Burocratic proceedings should be decreased.

7. Healthy egg and fry production should be promoted.

8. Local governments should appropriately use their authorities awarded to them in water renting. (Since local governments no longer have a say in water renting, this article is no longer in force)

9. The support for fry producers should be increased.

10. The high prices of the fishmeal should be tried to be decreased.

11. An enterprise with no business license should be prevented.

12. Personnel should be made to join in-service seminars periodically.

13. The producer should be able to sell the stock that it produced directly to the consumer.

Example of the second Delphi Questionnaire; "The aim of this second questionnaire is to present you the entire articles of the questions notified to you via the first questionnaire and to determine your level of participation in these articles. On the scale, " 1 " defines "I 
do not agree at all," while "7" defines "I absolutely agree". Indicate your level of participation between parentheses for each question. Furthermore explain briefly the reason why you agree/disagree with each article." Analysis of the second Delphi questionnaire is calculated with the first quarter, second quarter, square and span values of each article. Except from this, comments on each article such as agreeing/disagreeing, regard/disregard are gathered in an additional form. The results of the second Delphi method received from the experts are given on Table 3.

Table 3. Answers given by the Expert delegation for the second questionnaire

\begin{tabular}{lccccccccccccc}
\hline \hline Experts & Cul:1 & Cul:2 & Cul:3 & Cul:4 & Cul:5 & Cul:6 & Cul:7 & Cul:8 & \multicolumn{3}{c}{ Cul:9 } & Cul:10 Cul:11 Cul:12 Cul:13 \\
\hline 1. & 7 & 1 & 7 & 7 & 7 & 7 & 7 & 7 & 7 & 7 & 7 & 7 & 7 \\
2. & 5 & 5 & 7 & 2 & 7 & 3 & 1 & 3 & 2 & 7 & 7 & 7 & 2 \\
3. & 3 & 7 & 4 & 1 & 7 & 7 & 7 & 7 & 7 & 7 & 7 & 7 & 7 \\
$\mathbf{4 .}$ & 7 & 1 & 7 & 3 & 7 & 7 & 7 & 7 & 7 & 7 & 7 & 7 & 7 \\
$\mathbf{5 .}$ & 7 & 1 & 7 & 1 & 7 & 7 & 7 & 7 & 7 & 7 & 7 & 7 & 7 \\
$\mathbf{6}$ & 2 & 7 & 7 & 1 & 7 & 7 & 7 & 7 & 7 & 7 & 7 & 7 & 1 \\
7. & 4 & 4 & 4 & 4 & 4 & 7 & 4 & 7 & 4 & 7 & 4 & 4 & 4 \\
$\mathbf{8 .}$ & 6 & 7 & 7 & 4 & 1 & 7 & 7 & 6 & 6 & 7 & 7 & 6 & 4 \\
9. & 1 & 7 & 7 & 7 & 7 & 7 & 7 & 7 & 7 & 7 & 7 & 7 & 7 \\
10. & 1 & 5 & 7 & 1 & 7 & 7 & 7 & 6 & 2 & 7 & 7 & 7 & 7 \\
Median & 4,50 & 5,00 & 7,00 & 2,50 & 7,00 & 7,00 & 7,00 & 7,00 & 7,00 & 7,00 & 7,00 & 7,00 & 7,00 \\
Q1 & 1,75 & 1,00 & 6,25 & 1,00 & 6,25 & 7,00 & 6,25 & 6,00 & 3,50 & 7,00 & 7,00 & 6,75 & 3,50 \\
Q3 & 7,00 & 7,00 & 7,00 & 4,75 & 7,00 & 7,00 & 7,00 & 7,00 & 7,00 & 7,00 & 7,00 & 7,00 & 7,00 \\
R=Q1-Q3 & 5,25 & 6,00 & 0,75 & 3,75 & 0,75 & 0 & 0,75 & 1,0 & 3,5 & 0 & 0 & 0,25 & 3,5 \\
\hline \hline
\end{tabular}

Range $(\mathrm{R})$ : It is the difference between the third and the first quarter $(\mathrm{R}=\mathrm{Q} 3$ - $\mathrm{QI})$. If this difference is law this shows that there is a consensus, if it is high this shows that there isno consensus. In the case where the value of the range $(\mathrm{R})$ is lower than 1.2 this means thereis a consensus on the article of competence. In this case, the Agreed Competence Articles ofthe Second Delphi Questionnaire are as follows:

1. Pre-study (Agriculture Institution or other institutions of the city) is enough in the project stage.

2. There are problems faced in the stage of renting.

4. Official figures (eggs, fry and portion) represent production figures.

9. The support for fry producers should be increased.

13. The producer should be able to sell the stock that it produced directly to the consumer.

Since the R=Q3-Q1 valuesare low in the Cul:3,5,6,7,8,10,11 and12; the consensus has been achieved among the participants.

Question 3, 5, 6, 7, 8, 10, 11 and 12. R = Q3-Q1 value is low. Therefore, consensus is achieved among the participants.

At the following stage, the third Delphi Questionnaire consists of the agreed competence articles of the second questionnaire. In this questionnaire, at the beginning of each article there is information on the first quarter, second quarter, third quarter, square and span which are all calculated regarding the questionnaire. In the directive, the meaning of these statistics is explained to the participants with examples. The answers given by the participants for each article in the second questionnaire are added to the 
articles and a final decision is asked to be made. It is vital that the participants understand the data provided in the third Delphi questionnaire for the article.

In the letters sent to the experts the following statements are used. "The present third questionnaire sent to you is the same of the second; however, the statistical results of the second questionnaire are added. First of all, the answers given by you in the second questionnaire are given at the beginning of the each article. In addition to your answers there are four different results of the statistics regarding the answers of the group: the first quarter (Q1), Median (Md), third quarter (Q3) and Range (R).

Evaluation of the Competence Articles:

'1. Pre-study is enough in the project stage.

For this competence article, no consensus is provided in the second Delphi questionnaire and this competence article is presented to the participant expert delegation in the third questionnaire. At the end of the third and the last questionnaire, no consensus has been reached for this article.

"2. There are problems faced in the stage of renting."

For this competence article, no consensus is provided in the second Delphi questionnaire and this competence article is presented again to the participant expert delegation in the third questionnaire. While some experts highlight that there are problems on this subject, some others have stated that there are no problems. Consequently, at the end of the third and the last questionnaire, no consensus has been reached for this article.

"3. A production planning is made according to regions and the conditions of the environment."

For this competence article a consensus has been reached at the end of the second questionnaire. Expert delegation who is composed of the participants in this study has decided that aquaculture should be carried out suitable to the conditions arising from the regions and the environment. The third stage is not needed for this article.

"4. Official figures (eggs, fry and portion) represent production figures."

As no consensus is provided in the second Delphi questionnaire for this competence article, it is broached to the expert delegation again in the third stage. At the end of the questionnaire, no consensus could be reached for this article. Some among the expert delegation claims that there is a non-recorded aspect in this case.

"5. The Ministry should have a sufficient number of staff for fighting with the diseases."

For this competence article a consensus has been reached at the end of the second questionnaire. The expert delegation who was the participant of the study supports the idea that individual fight by the enterprise against the diseases is not enough. That is why the support of the ministry is needed against the epidemics which have risen in the enterprises.

"6. Bureaucratic proceedings should be decreased."

For this competence article a consensus has been reached at the end of the second questionnaire. According to the expert delegation of the study, the bureaucratic proceedings during the process of opening an enterprise and of operating an existing enterprise pose an obstacle before the operators.

"7. Healthy egg and fry production should be promoted."

For this competence article a consensus has been reached at the end of the second questionnaire. According to the expert delegation, raising the pure brood stocks and 
accordingly obtaining healthy fries are crucial for the development and sustainability of the trout aquaculture.

"8. Local governments should appropriately use their authorities awarded to them in water renting."

Since local governments no longer have a say in water renting, this article is no longer in force.

"9. The support for fry producers should be increased."

As no consensus is provided in the second Delphi questionnaire for this competence article, it is broached to the expert delegation again in the third stage. At the end of the questionnaire, no consensus could be reached for this article. Since the number of enterprises cultivating fries among the delegation of experts selected for this study, the delegation could not reach a consensus in this respect.

"10. The high prices of the fishmeal should be tried to be decreased."

For this competence article a consensus has been reached at the end of the second questionnaire. According to the expert delegation the prices of the fishmeal used in the trout aquaculture pose a burden on the shoulders of the enterprises. Fishmeal prices should be decreased into reasonable prices in order to provide sustainability of the sector.

"11. An enterprise with no business license should be prevented."

For this competence article a consensus has been reached at the end of the second questionnaire. According to the expert delegation, first of all the enterprises without licenseshould be tried to be licensed. Those enterprises which are not licensed at the end of these proceedings should be closed down.

"12. Personnel should be made to join in-service seminars periodically."

For this competence article a consensus has been reached at the end of the second questionnaire. According to the expert delegation, personnel should be informed about the innovations and developments in the sector by means of seminars. People who are to train the personnel must be well-informed about the sector.

"13. The producer should be able to sell the stock that it produced directly to the consumer."

As no consensus is provided in the second Delphi questionnaire for this competence article, it is broached to the expert delegation again in the third stage. At the end of the questionnaire, no consensus could be reached for this article.

\section{RESULT and DISCUSSION}

Standing as a type of aquaculture practiced in our country and as the most successfullyapplied one, trout aquaculture has improved drastically since 1970s. Being known by our society as a type of fish which could only be cultivated in fresh waters during the first years when the production works were launched, trout is cultivated in more than 1700 enterprises by a production capacity of nearly 101 thousand tons today. When these figures are taken into consideration, the contribution of the trout aquaculture sector to the economy of the country is considerably significant. A swift chance and development have been observed with the increase in the demand for aquaculture in the last 20 years within the trout aquaculture works which have been carried out more than 40 years. Depending on the increase of the population, increase in the demand on both fish and the foods of animal origin are the main reason of this change and development. In addition to these reasons, we can also mention the critical contribution of the sector to Turkey economy. 
Accordingly, the number and the capacity of the enterprises built on the water resources are getting more and more close to the maximum value supportable by the water capacity. It is inevitable that trout sector faces certain problems eventually like every sector where the demand rises and which is developing. For a comprehensive determination and resolution of these problems, the competent experts working as an employee or employer in this sector should be gathered and their opinions should be listened.

Gathering the experts for the resolution of the problem poses a critical obstacle within this process. Due to the problems caused by the limitations related to time and to the spatial differences, things come even closer to a dead-end. In such cases, scientific methods which can overcome the obstacles of time and space should be used. Standing as a questionnaire method which is composed of a few stages and which has the capacity to gather the experts without encountering the obstacles of time and space, Delphi method was found suitable for this study.

According to the expert opinions acquired in questionnaire results, first of all following measures should be taken in order to take steps for the resolution of the problems of the trout aquaculture and for the improvement of the sector in Turkey:

Each region has different climatic and physical conditions. For this reason, production should be made within the conditions determined according to the environmental features of the region in order to increase the efficiency and to minimize the potential problems.

In the fight with diseases, it is crucial for the ministry not to leave the enterprise where the disease is detected but to support and inspect it.

The bureaucratic formalities required for establishing an enterprise, maintaining the production and putting the produced stock on market should be decreased.

For a quality and high efficiency production, pure fry and egg production from disease should be encouraged. It is an obligation to respect the quarantine and hygienic measures and for the authorities to rigorously inspect this process.

Fishmeal prices are high. Therefore the prices should be reduced without decreasing the quality of fishmeal. Reducing the charged taxes may be a good solution for this problem.

The state support prices should be declared within a period which would not aggrieve the enterprises.

License is required for an enterprise. Those enterprises which does not have a license or which cannot be licensed should be closed down.

The personnel of an enterprise should receive periodical in-service training given by the qualified people in order to keep up with the changes.

When the capital structures of the enterprises and the opinions of the operators are taken into consideration, it can be stated that enterprises need loans. The high interest rate of loans and bureaucratic obstacles affect the use of loans by the enterprises in a negative way.

It has been found out that there is no organization between the enterprises. The point of cooperating is crucial because of its advantages at the input provision and marketing stage. Cooperating will not only enable enterprises to be able to obtain their need of input collectively for a reasonable price but also provide an opportunity to overcome the competition problem in the market. 
Suggestions regarding the solution of the problems faced by the enterprises can be summarized as follows:

In order to increase the operators' knowledge on the trout production and management, it will be beneficial if the Provincial/District Directorates of Agriculture organize courses and seminars in the related departments of the universities. It will be beneficial if the institutions providing loans for meeting the loan requirements of the enterprises considering the present status of the enterprises.

Fish consumption is $8 \mathrm{~kg}$ in Turkey. $80 \%$ of the produced trout is exported. However, delivering trout which is highly rich in terms of nutrients to the consumers at first hand increases the consumption. For this purpose, works promoting fish consumption should be conducted by the producers and related institutions collectively.

Enterprises should be supported sufficiently by the related institutions both at the stage of establishment and at the stage of production of the enterprises. Cooperation is a must in the resolution of the problems generally faced by the enterprises. The best association to be established is production and selling cooperative. However this cooperative should not only be in the producers' level but also Provincial/District Directorates of Agriculture, universities, territorial and local authorities should be a part of this organization actively. Hereby, the existing enterprises may be enabled to work more efficiently and voluntarily and an environment of confidence can be built for the enterprises to be established.

A minimum price enabling purchase should be set by the State Meat and Fish Authority in order to prevent the fishes to lost value when they are landed by net cage enterprises producing seasonal trout (autumn-winter).

In conclusion it is obvious that, with the resolution of the problems set forth by the experts working actively in the trout aquaculture sector in various regions of Turkey, the sector shall make progress both in economic and in scientific terms in our country.

\section{Acknowledgments}

This study was funded by Ege University, Scientific Research Project, 10-SUF-023.

\section{How to Cite}

Sayğı H., Canyurt M. A., Güner Y., Güleç F., Işıı G. 2016. Alabalık İşletmeleri ve Delphi Anket Yöntemi. Eğirdir Su Ürünleri Fakültesi Dergisi. 12(1), 25-36.

\section{REFERENCES}

Canyurt, M.A., Akhan, S., 2009. Development and Situation Of Trout CultureInTurkey.15. International Scientific Conference- Research For Rural Development 2009. Annual $15^{\text {th }}$ International Scientific Conference Proceedings. Latvia University of Agriculture, 19-21 May 2009, pp. 90-94, Jelgava, Latvia.

Canyurt, M.A., Guner, Y., Toksen, E.,2009. Sustainable Development of Aquaculture in Turkeyand Its Constraints. 1. International Symposium on Sustainable Development, Science and Technology Proceedings, 3:45-49, International Burch University, June 9-10 2009, Sarajevo

Canyurt, M.A., 2010. Bozdoğan's Evaluation of water potential and Fisheries. 13-15 May 2010, Environment and Culture Symposium in Bozdoğan. Bozdoğan, Aydın.

Canyurt, M.A., 2010. Sustainable Aquaculture and Environmental Interaction. Second International Symposium On Sustainable Development.June 8-9, 2010, Sarajevo., International BurchUniversity Publications, pp. 678-682. 
Canyurt, M.A., 2010.Cultivation of trout in Turkeyyesterday, todayandthen future. 2. Trout Symposium, Karamanoğlu Mehmetbey University. 6-8 july 2010, Ermenek, Karaman

Dalkey, N., Helmer, O., 1962. An Experimental Application of the Delphi MethodtotheUse of ExpertsThe RAND Corporation, Santa Monica.

Duvarc1, Y., Selvi, Ö., Günaydın, H.M. And Gür, G., 2008.TheEffects of Transportation Projects on Urban Trends in İzmir, İMO Technical Journals, 4293-4318, article283

Erlfmeyer, R., Erffmeyer, E. andLane, I. 1986.The Delphi Technique: An Empirical Evaluation of the Optimal Number of Raunds. Group\&Organization Management, 11(1-2), 120-129.

Güven, M., Kürüm, D., 2006.Relationshipbetweenlearningstylesandcriticalthinking a general overview, Social sciences journals2006/1

Linstone, H. and Turoff, M., 1975. "Introduction" The Delphi Method: Techniques and Applications Linstone and Turoff (Editörler) Addison- Wesley Publishing Company, London.

Linstone, H. And Tomlın, M., 1975. "The Delphi Method: Techniques and Applications", Reading, MA:Addison-Wesley.

Pollard, R., Tamlın, M., 1995. "TheUse of Expert Teachers to Improve Education." Education, 116(1), 3-9.

Quinn, P., 1986. "Utilization-Focused Evaluation." Newbury Park, CA: Sage Publications.

Rothwell, W.J., Kazansas, H.C., 1997. "Mastering The Instructional Design Process: A Systematic Approach", San Francisco: Jossey- Bass.

Rowe, G., Wright, G., Bolger, F., 1991. "Delphi: A reevaluation of Research and Theory" TechnologicalForecastingandSocialChangeVol39, 23S-251.

Saekman, H., 1975. "Delphi Critique: Expert Opinion", Lexington, MA: Lexington Books.

Şahın, A.E., 2001. "Delphi technique and itsuses in educational" Hacettepe University the Journal of Education20: 215 - 220.

Turoff, M., H1ltz, S.R., 2001. "Computer Based Delphi Processes" London: Kingsley.

Woudenberg, F., 1991. "An Evaluation of Delphi" Technological Forecastingand Social Change 40, 131-150.

Zelıff, N.D., Heldenbrand, S.S., 1993. "What Has Being Done InThe International Business Curriculum?" Business Education Forum, 48(1), 23-25. 